THE CANADIAN JOURNAL OF AUTISM EQUITY LA REVUE CANADIENNE DE L'ÉQUITÉ EN MATIÈRE D'AUTISME VOLUME 1 ISSUE 1 APRIL 2021

\title{
Are We Equal
}

Terri Robson, Awkward Spirit: Looking Beyond the Mask, Canada 


\title{
Are We Equal
}

\author{
Terri Robson ${ }^{1}$
}

\begin{abstract}
The poems are the musings of an Aspie (not ableist, just how I refer to myself) mind, wondering where, how and if I fit in. I would suspect many on the spectrum ask these questions, or others similar in nature, themselves. I often wonder if I shouldn't just create my own niche and have you meet me there. In many ways I already have.

\section{Résumé}

Ces poèmes sont des réflexions tirées de l'esprit d'une personne Asperger (pas par capacitisme; c'est seulement la façon dont je me désigne), qui se demande où, comment et si elle est à sa place. Je soupçonne que beaucoup de personnes sur le spectre se posent ces mêmes questions, ou du moins des questions de nature similaire. Je me demande souvent si je ne devrais pas simplement créer mon propre créneau et inviter les autres à m'y rejoindre. À bien des égards, c'est déjà le cas.
\end{abstract}

\section{Keywords}

Equity, Unique, Adrift, Trapezoid, Square Peg Round Role Mots clés

Équité, Unique, à la dérive, trapèze, cheville carrée dans un trou rond

\footnotetext{
1 Awkward Spirit: Looking Beyond the Mask, Canada
} 


\section{Who Are We?}

What moment are we in?

Strong, resilient

Melting down, resentful

What day is this?

Good with minor moments of fear and angst

Can I push through?

I have some tools in my toolbox

Are they right for this situation?

Is it time for hard learning, a search for different tools?

Not necessarily better, just new

Struggling with old patterns

Behaviours

They don't work with the evolving individual

For worse or better for the ever-changing group 


\section{Dissimilar}

Normal: a setting on a dryer

Typical: conforming

Conforming: to become similar in nature or character; to be in harmony

Autistic: to be none of the above and unique unto oneself

\section{Adrift}

I feel adrift on a sea of emotion

Restless on a raft of my own making

Where is this sea upon which I float

Was it you, was it me, who put me here? 


\section{Walking}

Walking

Around twilight

in the dark,

bumping into things at your own peril

My life in a day as an Aspie

Crashing into awkward social situations, Questions I don't know how to answer

Conversations I don't know how to participate in

You slide seamlessly into it all

A round peg made perfectly to fit into life's whole

I feel like a square peg, 4 corners to fit in a triangle

Do I fit anywhere? Maybe I'm a trapezoid.

You look at me; I don't look square

Yet I don't react and respond like you

I am different, but I am the same

Thoughts, emotions, questions, opinions

Just different from yours

Each one of you I meet has differing thoughts and emotions

Do you question most things so you know how you fit in I must. I need to know how to fit into this strange world Will I? See me as those similar to me do and give us a chance.

You'll see. We can walk together. 


\section{Am Ready}

I am ready,

Are you?

I am willing,

Are you?

I am able,

Are you?

I am all these things and more

Capable, honest, trustworthy,

Hard-working, loyal,

Willing to learn, to grow, to flourish

Teach me, work with me

Learn with me and grow with me Together we'll make a difference 


\section{Opportunities}

What don't you see in me Is it the magic, the wonder I see every day Why don't you see my talents, my gifts, My everyday quirks I too can do what you do, But it may be done differently Different doesn't mean wrong It means not the same

Your talents and gifts are different than mine They are what make you unique Yet the world welcomes many of you With open arms, open doors, Open opportunities

Why then are those openings closed to others like me I do not want to change, I only want to be me Please give me the same opportunities You'll see who I can be 